\title{
Adenosine A2B receptor: novel anti-cancer therapeutic implications
}

\author{
Silvia Paola Corona ${ }^{1}$, Navid Sobhani ${ }^{2}$, Daniele Generali ${ }^{2}$ \\ ${ }^{1}$ Department of Radiation Oncology, Peter MacCallum Cancer Center, Moorabbin Campus, Bentleigh East VIC 3165, Australia. \\ ${ }^{2}$ Department of Medical, Surgery and Health Sciences, University of Trieste, 34129 Trieste, Italy.
}

\begin{abstract}
Correspondence to: Dr. Silvia Paola Corona, Department of Radiation Oncology, Peter MacCallum Cancer Center, Moorabbin Campus, Bentleigh East VIC 3165, Australia. E-mail: sil.corona@hotmail.it
\end{abstract}

How to cite this article: Corona SP, Sobhani N, Generali D. Adenosine A2B receptor: novel anti-cancer therapeutic implications. J Cancer Metastasis Treat 2017;3:206-8.

Article history: Received: 4 Aug 2017 Accepted: 15 Sep $2017 \quad$ Published: 27 Sep 2017

Extracellular adenosine is a product of the metabolism of nucleotides such as ATP and ADP and mediates a wide range of events under normal and pathological conditions ${ }^{[1,2]}$. Adenosine receptors belong to the G-coupled signalling receptors and are broadly expressed in normal tissues in 4 subtypes $(\mathrm{A} 1, \mathrm{~A} 2 \mathrm{~A}, \mathrm{~A} 2 \mathrm{~B}, \mathrm{~A} 3)$.

While A2B has traditionally been considered of less relevance in comparison to $A 2 A$ due to lower affinity of the ligand for this adenosine receptor subtype, recent evidence strongly suggests a specific role of this receptor in cancer and other pathological conditions ${ }^{[3,4]}$.

The authors of this review are experts in the field of adenosine signalling. In this work they analyse the oncogenic role of the $A 2 B$ receptor, also proposing and discussing its targeted blockade as a new anticancer therapeutic option.

As they explain, the mechanisms thought to be involved in A2B-mediated tumour progression are multiple. Adenosine is responsible for modulating the tumour microenvironment and the phenomenon of angiogenesis via production of growth factors, cytokines and chemokines. Also, it is involved in the regulation of dendritic cells and macrophages differentiation and function, aspects, these, crucial for tumour immune-surveillance. Lastly, via its $A 2 B$ receptor, adenosine modulates the inflammatory response to the tumour and promotes tumour cells migration and therefore metastasis.

The effects of protracted inflammation can be devastating on normal tissues. Adenosine modulates inflammation by enhancing differentiation of T-regulatory and myeloid derived suppressor cells which are able to induce T-cells anergy ${ }^{[5]}$. Also, through its $\mathrm{A} 2 \mathrm{~B}$ receptor, adenosine induces antiinflammatory cytokines such as IL-10, further limiting the amplification of the inflammatory biochemical cascade. On the other hand, activation of the A2B receptor can be associated with pro-inflammatory effects through activation of mast cells, fibroblasts and other epithelial cells, such as intestinal cells ${ }^{[6]}$. The pro- or anti-inflammatory action of adenosine has been subject to extensive study and debate through the recent years and it seems to be dependent on specific cell type and extracellular microenvironment ${ }^{[7,8]}$. 
Phylogenetically, both the anti-inflammatory and the pro-inflammatory actions of adenosine have a protective function, the first keeping in check the cascade of events typical of inflammation and thus avoiding tissue damage, the second facilitating the reaction to and elimination of foreign pathogens.

Exactly as it is the case for other immunecheckpoints, tumour cells can exploit these defence mechanisms to induce immune suppression and cancer-tolerance. In this context, the expression of A2B in immune cells has attracted a lot of attention, as the receptor seems to drive the expansion of immunosuppressive, pro-angiogenic and cancer tolerant cells ${ }^{[9]}$. For these reasons, adenosine may be considered itself an immune-modulatory checkpoint molecule ${ }^{[10]}$. This hypothesis is further strengthened by evidence of a synergic anti-tumour effect elicited combining anti-PD-1 (or CTLA-4) and adenosine signalling inhibitors ${ }^{[11-14]}$. This synergism requires CD73 (one of the nucleotidases involved in adenosine generation) expression on tumour cells, suggesting that the adenosine produced in the context of the tumour could interfere with the effect of targeted immunotherapies ${ }^{[13]}$. The addition of A2A- or A2B-receptor inhibitors to current targeted immunotherapies could therefore represent a means to overcome acquired resistance to such treatments.

It is worth noting that, besides the effects of adenosine and $\mathrm{A} 2 \mathrm{~B}$ on the immune system, the expression of this receptor on the surface of cancer cells seems to mediate important oncogenic effects in a variety of cancers. Pharmacological inhibition or knockdown of $A 2 B$ decreases proliferation of tumour cell| ${ }^{[15-17]}$ and a role for $A 2 B$ in tumour progression and metastasis is supported by multiple studies in bladder, breast, colon, prostate and other cancers ${ }^{[14,15,18-20]}$.

In particular in triple negative breast cancer, expression of CD73 is associated with poor prognosis and pharmacological resistance to doxorubicin ${ }^{[21]}$. Similarly, high expression of A2B in cancer cells increases invasiveness and metastasis and is a predictor of poor prognosis and shorter survival in triple negative breast cancer $(T N B C)^{[19]}$. On the other hand, presence of $A 2 B$ in the host immune cells does not impact the metastatic potential of TNBC tumour cells in the same metastatic mouse models of breast carcinoma, as demonstrated by the fact that blockade of tumour-expressed $\mathrm{A} 2 \mathrm{~B}$ receptor, in $A 2 B$ receptor-deficient mice, reduces the metastatic burden from TNBC cell lines xenografts.

Moreover, constitutive activation of the adenosine receptor $\mathrm{A} 2 \mathrm{~B}$ in response to a hypoxic microenvironment has been associated with increased proliferation of prostate cancer cells in vitro ${ }^{[20]}$.

Lastly, the A2B receptor has been shown to activate downstream oncogenic pathways frequently mutated in cancer such as mitogen-activated protein kinase $\mathrm{e}^{[18,19]}$, as well as phospholipase $\mathrm{C}$, cathelicidin antimicrobial peptide, NFkB1 and arachidonic acid signalling. Moreover, A2B is also a downstream target of the transcription factor Fosrelated Antigen-1 (Fra-1), a gene involved in the development of metastasis ${ }^{[16]}$. A2B pharmacological blockade in Fra-1 positive breast cancer cells inhibited metastasis to the lungs in a mouse model of metastatic breast cancer. In the near future, it is possible that identification of Fra-1 positive tumours will guide the stratification of patients that are most likely to respond to $A 2 B$ inhibitors.

Notwithstanding the mounting evidence in favour of an oncogenic role for $\mathrm{A} 2 \mathrm{~B}$, most of the data supporting this hypothesis come from pre-clinical studies in vitro. Whilst A2A small molecule inhibitors are already in clinical development (NCT02403193 and NCT02655822), the same cannot be said for $\mathrm{A} 2 \mathrm{~B}$ receptor inhibitors. All the $\mathrm{A} 2 \mathrm{~B}$ receptor inhibitors have been tested in vitro and in vivo, but their pharmacokinetic characteristics are still mostly unknown.

A2B has the potential to become a therapeutic target, at least in tumours overexpressing the protein. However, more studies are needed to explore all the functions of the $\mathrm{A} 2 \mathrm{~B}$ receptor and its ligand, particularly with the aim of gaining a better understanding of the multiple $\mathrm{A} 2 \mathrm{~B}$ receptorindependent metabolic effects of adenosine ${ }^{[22]}$.

Moreover, due to the extensive cross-talk and the number of molecular targets involved with the adenosine signalling pathway, and considering the ubiquitousness of the receptors, it is conceivable that side effects of the inhibition of CD73, A2A and A2B could represent an issue in the clinical setting.

Finding strategies to specifically target receptors expressed on tumour cells could help mitigate the toxicity of these agents. Also, using these drugs in combination with other targeted agents, as it is already the case with A2A-inhibitors, will hopefully further decrease toxicities by exploiting the synergism shown in combination therapy.

Finally, pharmacologically modulating metabolic conditions such as hypoxia should likely increase the effectiveness of these molecules. 
Accumulating knowledge of the adenosine signalling targets drives the identification of biomarkers and predictors of response/resistance, opening therefore the possibility of a personalised therapeutic approach.

\section{DECLARATIONS}

\section{Authors' contributions}

Concept and design of the article: S.P. Corona, N. Sobhani, D. Generali

Definition of intellectual content, literature search and manuscript preparation: S.P. Corona

Manuscript editing: S.P. Corona, D. Generali

\section{Financial support and sponsorship} None.

\section{Conflicts of interest}

There are no conflicts of interest.

\section{Patient consent \\ Not applicable.}

\section{Ethics approval}

Not applicable.

\section{REFERENCES}

1. Ohta A, Sitkovsky M. Extracellular adenosine-mediated modulation of regulatory T cells. Front Immunol 2014;5:304.

2. Borea PA, Gessi S, Merighi S, Varani K. Adenosine as a multisignalling guardian angel in human diseases: when, where and how does it exert its protective effects? Trends Pharmacol Sci 2016;37:419-34.

3. Sun Y, Huang P. Adenosine A2B receptor: from cell biology to human diseases. Front Chem 2016;4:37.

4. Sorrentino C, Morello S. Role of adenosine in tumor progression: focus on A2B receptor as potential therapeutic target. $J$ Cancer Metastasis Treat 2017;3:127-38.

5. Ryzhov S, Novitskiy SV, Goldstein AE, Biktasova A, Blackburn MR, Biaggioni I, Dikov MM, Feoktistov I. Adenosinergic regulation of the expansion and immunosuppressive activity of CD11b+Gr1+ cells. J Immunol 2011;187:6120-9.

6. Haskó G, Csóka B, Németh ZH, Vizi ES, Pacher P. A(2B) adenosine receptors in immunity and inflammation. Trends Immunol 2009;30:263-70.

7. Aherne CM, Saeedi B, Collins CB, Masterson JC, McNamee EN, Perrenoud L, Rapp CR, Curtis VF, Bayless A, Fletcher A, Glover LE, Evans CM, Jedlicka P, Furuta GT, de Zoeten EF, Colgan SP, Eltzschig HK. Epithelial-specific A2B adenosine receptor signaling protects the colonic epithelial barrier during acute colitis. Mucosal Immunol $2015 ; 8: 1324-38$.

8. Merighi S, Bencivenni S, Vincenzi F, Varani K, Borea PA, Gessi S. A2B adenosine receptors stimulate IL-6 production in primary murine microglia through p38 MAPK kinase pathway. Pharmacol Res 2017;117:9-19.

9. Novitskiy SV, Ryzhov S, Zaynagetdinov R, Goldstein AE, Huang Y, Tikhomirov OY, Blackburn MR, Biaggioni I, Carbone DP, Feoktistov I, Dikov MM. Adenosine receptors in regulation of dendritic cell differentiation and function. Blood 2008;112:1822-31.

10. Whiteside TL. Targeting adenosine in cancer immunotherapy: a review of recent progress. Expert Rev Anticancer Ther 2017; 17:527-35.

11. Mittal D, Young A, Stannard K, Yong M, Teng MW, Allard B, Stagg J, Smyth MJ. Antimetastatic effects of blocking PD-1 and the adenosine A2A receptor. Cancer Res 2014;74:3652-8.

12. Allard B, Pommey S, Smyth MJ, Stagg J. TTargeting CD73 enhances the antitumor activity of anti-PD-1 and anti-CTLA-4 mAbs. Clin Cancer Res 2013;19:5626-35.

13. Iannone R, Miele L, Maiolino P, Pinto A, Morello S. Adenosine limits the therapeutic effectiveness of anti-CTLA4 $\mathrm{mAb}$ in a mouse melanoma model. Am J Cancer Res 2014;4:172-81.

14. Beavis PA, Milenkovski N, Henderson MA, John LB, Allard B, Loi S, Kershaw MH, Stagg J, Darcy PK. Adenosine receptor 2A blockade increases the efficacy of Anti-PD-1 through enhanced antitumor T-cell responses. Cancer Immunol Res 2015;3:506-17.

15. Ma DF, Kondo T, Nakazawa T, Niu DF, Mochizuki K, Kawasaki T, Yamane T, Katoh R. Hypoxia-inducible adenosine A2B receptor modulates proliferation of colon carcinoma cells. Hum Pathol 2010;41:1550-7.

16. Desmet CJ, Gallenne T, Prieur A, Reyal F, Visser NL, Wittner BS, Smit MA, Geiger TR, Laoukili J, Iskit S, Rodenko B, Zwart W, Evers B, Horlings H, Ajouaou A, Zevenhoven J, van Vliet M, Ramaswamy S, Wessels LF, Peeper DS. Identification of a pharmacologically tractable Fra-1/ADORA2B axis promoting breast cancer metastasis. Proc Natl Acad Sci U S A 2013;110:5139-44.

17. Kasama H, Sakamoto Y, Kasamatsu A, Okamoto A, Koyama T, Minakawa Y, Ogawara K, Yokoe H, Shiiba M, Tanzawa H, Uzawa K. Adenosine $\mathrm{A} 2 \mathrm{~b}$ receptor promotes progression of human oral cancer. BMC Cancer 2015;15:563.

18. Zhou Y, Chu X, Deng F, Tong L, Tong G, Yi Y, Liu J, Tang J, Tang Y, Xia Y, Dai Y. The adenosine A2b receptor promotes tumor progression of bladder urothelial carcinoma by enhancing MAPK signaling pathway. Oncotarget 2017;8:48755-68.

19. Mittal D, Sinha D, Barkauskas D, Young A, Kalimutho M, Stannard K, Caramia F, Haibe-Kains B, Stagg J, Khanna KK, Loi S, Smyth MJ. Adenosine 2B receptor expression on cancer cells promotes metastasis. Cancer Res 2016;76:4372-82.

20. Vecchio EA, Tan CY, Gregory KJ, Christopoulos A, White PJ, May LT. Ligand-independent adenosine A2B receptor constitutive activity as a promoter of prostate cancer cell proliferation. J Pharmacol Exp Ther 2016;357:36-44.

21. Loi S, Pommey S, Haibe-Kains B, Beavis PA, Darcy PK, Smyth MJ, Stagg J. CD73 promotes anthracycline resistance and poor prognosis in triple negative breast cancer. Proc Natl Acad Sci U S A 2013;110:11091-6.

22. Mølck C, Ryall J, Failla LM, Coates JL, Pascussi JM, Heath JK, Stewart G, Hollande F. The A2b adenosine receptor antagonist PSB-603 promotes oxidative phosphorylation and ROS production in colorectal cancer cells via adenosine receptor-independent mechanism. Cancer Lett 2016;383:135-43. 